\title{
Art as Symbol of Power and Control among the Yorùbá
}

\author{
Kehinde Adepegba \\ Department of Art and Industrial Design \\ School of Environmental Studies \\ Lagos State Polytechnic \\ Ikorodu, Nigeria \\ adepe200us@yahoo.com \\ Tolulope 0. Sobowale \\ Department of Fine and Applied Arts, \\ Faculty of Environmental Studies, \\ Olabisi Onabanjo University \\ Ago-Iwoye, Nigeria \\ tolucobbler2@gmail.com
}

\begin{abstract}
The Yorùbá are popular for the peculiar art forms, which include woodcarving, textile design, metalwork, cloth weaving and embroidery, beadwork, costuming, pottery, architectural ornamentation, mural paintings, body beautification among others. The Yorùbá artists produce unique forms in these diverse areas of art. These forms often bear visual renditions of symbolism that are pregnant with socio-political meanings. This paper is, therefore, aimed at examining the symbolism of power and control among the Yorùbá found on some of the art forms. This is with the view of understanding the belief of the people about power and its control in the development of the Yorùbá nation. Photographic data for the paper were gathered from written literature and fieldwork. Formal and contextual methods were employed in the analysis of the data. In the course of analysis, oral traditions such as songs, proverbs, etc. were used. It was found out that the exercise of socio-political power in the Yorùbá society is a product of their belief system and philosophy as expressed in their art forms.
\end{abstract}


Keywords: Belief system, Power and Control, Yorùbá Art Forms, Visual Symbolism

\section{Introduction}

The Yorùbá who occupy majorly the present day western parts of Nigeria and spread eastwards to the Republics of Benin and Togo, and across the Atlantic Ocean to Brazil, Cuba, Haiti and the United State of America (Adeoye 1979: 4), are one of the largest ethnic groups in Africa and renowned for their most complex cultures in the sub-Saharan Africa (Kissick 1993, 353; Lawal 2012, 11). For this complex culture, the Yorùbá art has emerged as one of the richest in the world going by its scale of production and variety of forms. Their diverse art practices and forms are products of their composite socio-cultural and religious beliefs (Adepegba2016, 1).

The diverse art forms of the Yorùbá include sculpture, textile, pottery, costumes, mural, beadwork, metalwork and architecture. The art forms serve numerous purposes, which include their use as metaphor or symbolism of the people's beliefs and philosophy. Hackett $(1996,56)$ asserts that African cultures have developed a rich and imaginative array of ritual forms-statues, carved pots, altars, stools, pots, textile as well as masks to give substance and life to the spiritual world. This, according to him without denying that they serve other purposes, the artistic forms allow humans some measure of conceptual access, communication and control. The Yorùbá artists always achieve communication of symbols, among other things in the course of ensuring socio-oneness among the people through the art.

The Yorùbá, from time immemorial, have used art for many purposes including the exercise of power. Through this culture-induced art of the Yorùbá, the sociology, philosophy, economic lifestyle, political system and most especially their traditional religion and belief system are comprehended (Adepegba 2016, 1). Art as an expression of power is of great essence among the people. The Yorùbá society, in their belief and cosmology understands that power is transient yet it is germane to humans and their relationships, and continued existence in order to guarantee order within the scope of continuity and change. Thus, they say: oba méwàa ìgà mẹwàa (the reign of ten kings unfold the reins of ten seasons) and igbà kan kò lo ilé ayé gbó (a season does not last forever).

Power and control among the Yorùbá manifest in many ways but these four dimensions are significant: socio-economic, religious, political and cultural. Socio-economic power resides in the rich who have the economic means to acquire properties and aspire to positions of authority. Hence, they say: olówó se ohun gbogbo tán (the rich can accomplish incredible feats). Socio-political power resides in the kings, chiefs, heads of compound and quarters, associations, age-grade groups, and others. Such leaders are highly referred because of the political power invested on them by their social groups. As they say: Ibi tí a bá pè lórí, enikan kií fi tẹlè (No one tramples on the one to 
whom leadership is ascribed). Socio-spiritual power resides in the ancestors, gods, diviners, and herbalists, to mention but a few. They possess the power that connects the physical environment with the spiritual realm. They are referred to as: Òmọràn tó ń mo oyún inú ìgbín (the wise one who discerns the unknown mysteries). These are the significant categories of people in the society who possess and exercise power and control.

Of course, a number of proverbs and songs support the belief of the people about powers in the hands of those who possess them.

Proverbs:

i. Eni tó bá juni lọ, ó lè juni nù

(One's superior can suppress one).

ii. Ibi tó bá wuè fúùfùlẹlẹ ló ń darí igbẹ sí

(Strong wind sways the bush to different directions).

Ibi tó bá wu olówó ẹni ló ń ránni lọ

(One's master can send one to any destination).

Song I:

A ó bá baba délé

Eni tí kò bá baba dele, ìyá ní ó jẹ

A ó bá baba délé.

(We shall walk the exalted one home

The one who does not walk him home, will be punished

We shall walk the exalted one home).

Song II:

Baba ni babańjẹ

Baba ni babań je

Ė báà tàkitì, kí ẹ forí solè

Baba ni babań je

(The referred one remains referred

The referred one remains referred

No matter what anybody does?

The referred one remains referred).

It is obvious that socio-cultural power is an interface of how the society has established the structure towards harnessing its socio-economic, religious and political relationships within the composite society. Visual art is one of the socio-cultural activities that reveal the beliefs of the people about power and control. It reveals a lot about their philosophy of power and remains an 
effective means of communicating how the strata of power and control are distributed among the people. Pemberton III $(1994,135)$ agrees that art is always part of a particular cultural tradition (àsà) and is created in the context of an artistic heritage within the larger cultural enterprise.

Frazer and Cole $(1972,310)$ assert that great many art objects from African cultures play a major part in the regulation of the society that is in the governing of the people. Likewise, art forms by the Yorùbá artists carry visual symbolism of power and control that are very effective as they influence the interactions of the people on special social occasions, festivals and at other interactional and relationship levels in the society. The Yorùbá believe that power is nothing, if it does not have control, which is why the society is organized such that power is devolved to reside in every level of the society. This serves as checks and balances mechanism in order to prevent its abuse. Therefore, there is no monopoly of power among the Yorùbá.

The study examines nine images (Plates 1-9), which serve as visual symbols from variant of media based on their forms and relatedness with the aim of underscoring how art serves as visual symbolism of power and control among the Yorùbá. Plates 1- 8 are from secondary sources while Plate 9 is a primary source. The images are analyzed using formal and contextual methods of analysis.

\section{Art as Visual Symbolism}

Yorùbá art are usually created such that they depict symbols that serve as metaphors of their belief and philosophy. The use of symbolism is an essential aspect of the people's life as a means of imparting and educating the people. Jefferson $(1974,20)$ discusses the four uses of symbol and motif in African art: (i) to record time-honored stories and legends (ii) serving as representations of ordinary tribal activities (iii) representations of deities and spirits and (iv) to be enjoyed merely for the sake of enjoyment. Also, Frazer and Cole $(1972,314)$, quoting Fortes and Evans-Pritchard, assert that members of African society feel their unity and perceive their common interest in symbols, and their attachment to their symbols. This is a concrete way of passing societal values to all and sundry, since everybody literarily interacts with the art and have the decoding knowledge of symbols used in their domain without stress.

These symbols are usually art-based and are very effective in creating social control and order. Conversely, as put by Kalilu and Areo $(2013,109)$, Yorùbá society are endowed with prolific intangible artistic tradition such as proverb, time honored stories, myths, legends, folklores, etc., from which most of the traditional motifs, patterns and symbols have been drawn. This symbolism sometimes requires explanation since African artists do not represent what he sees; his work always has some significance, which is not visible to the uninitiated (Carroll 1966, 27). 


\section{Analysis of Visual Symbolism of Art Forms}

The symbols that reveal the belief and philosophy of the Yorùbá on power and control as revealed in the nine selected works of art made of diverse media from different places within the Yorùbá nation, are analyzed as follows.

\section{I. Ẹkú Egúngún}

Egúngún fabric regalia (ẹkú) is a receptacle of the spirit of an ancestor. The ancestor pays intermittent visits to the world to bless members of his household, rid the community of diseases and settle family squabbles among others. Yorùbá people use this occasional physical appearance of the departed souls in Egúngún form as symbol of power and control over the living.

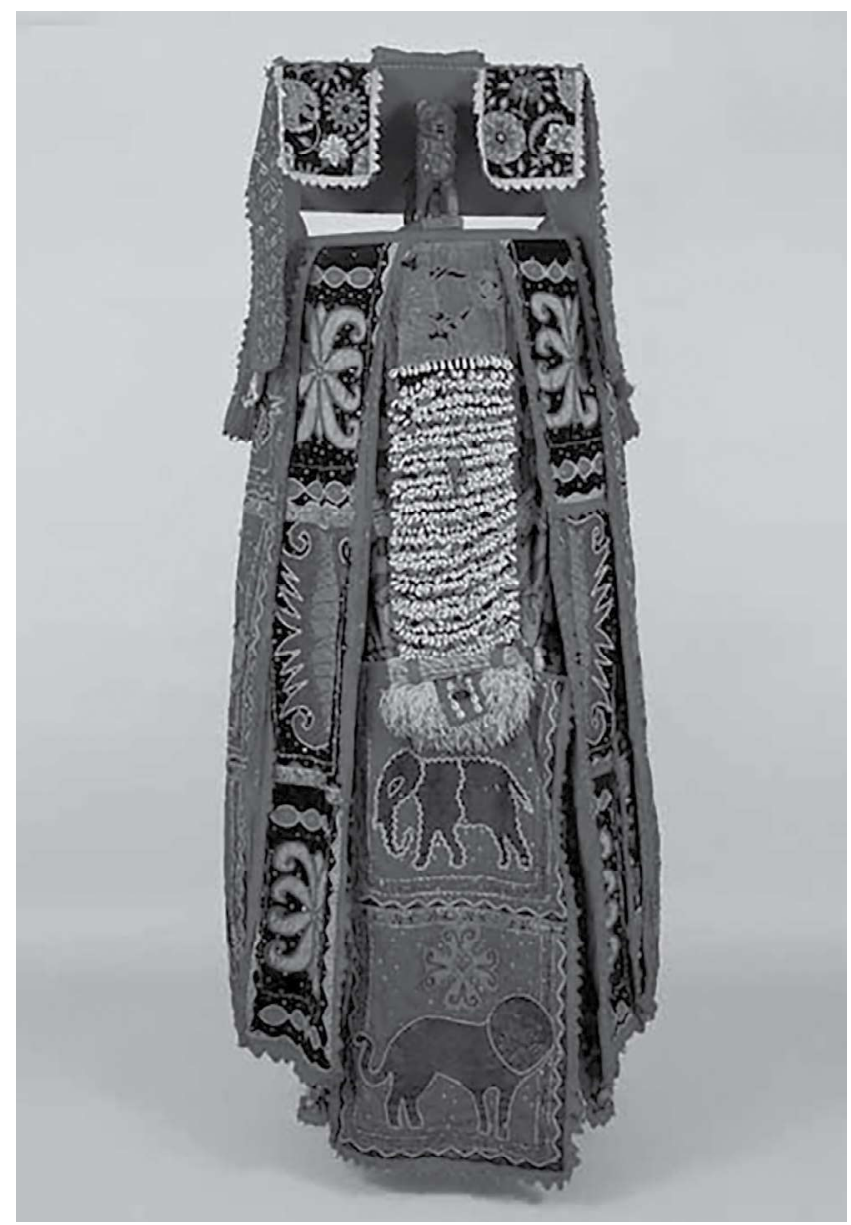

Plate 1:Ẹkú Egúngún. Assorted fabrics, appliqués, carved wood and cowries. Republic of Benin. 20th century.

Source: Newark Museum (2012) Embodying the Sacred in Yoruba Art. 
On the ẹ̀kú Egúngún the iconographic symbols of a lion and an elephant are imprinted. The symmetrical costume ensemble is made to incorporate floral embroidery made of red, black, and shades of greens and blues. These colors are such that accentuate attraction and attention to Egúngún during performance. The kinniún (lion) motif is of two types; the carved wooden figure attached on the headdress and the embroidery on the lower part of the costume. This is to relate the head to the body and the spiritual to the physical. This is probably done to emphasis the symbolic power attributable to the majesty of lion as king of the jungle. Hence this Yorùbá saying:

Ògòngò baba ẹẹ

Kiniún baba eranko

A juwọ́n lo tẹttẹtẹlè

Ojú ni wón ńyá.

(Ostrich is king of birds

Lion is king of animals

We have always been greater than them

They are only disrespectful).

This goes to show that the ancestor who is physically present in the form of Egúngún is superior to his living kinsmen that beckon him to come to help settle whatever problems they have or wade off any evil tormenting them. The Lion iconography may also connote the superiority and àsẹ (authority) of the Egúngún among the other ones in the community. Similarly the elephant also depicted is a metaphor of strength and might. As they say: itàkùn tó ní kérin má gòkè àlọ, tòun terin ló $n$ lo (the stumbling block in the way of the elephant will become its stepping stone).

Hence, the Egúngún combines power and strength through socio-religious symbols usually attached to its regalia and towards the enhancement of the control it has on the living. As we know, Egúngún is always a referred being, as reflected in this Yorùbá aphorism:

Eńikan kì kọlu Egúngún

Eńikan kì ta òrișà láyà.

(No one attacks Egúngún

No one challenge the gods).

\section{Kneeling Wooden Figure}

The kneeling altar figure carved in wood (see Plate 2) titled Arugbá Òṣun, signifies obeisance to the goddess of Ọșun. Òșun is the most beautiful 
goddess in Yorùbá pantheon (Folarin 2004, 356). The figure represents both an Ọșun worshipper and the Ọșun herself. This naturalistic image represents due reverence made by this kolanut-bearing kneeling figure in total submission to the power of the Ọșun goddess. The gods and goddesses among the people are often referred to as òrìsà-àkúnlẹ-bo (the gods/goddesses that are worshipped in kneeling posture). Kneeling figure and its unique proportion is one of the common elements ${ }^{1}$ that differentiate their carvings from those of other non-Yorùbá people (Adepegba 2007, 20).

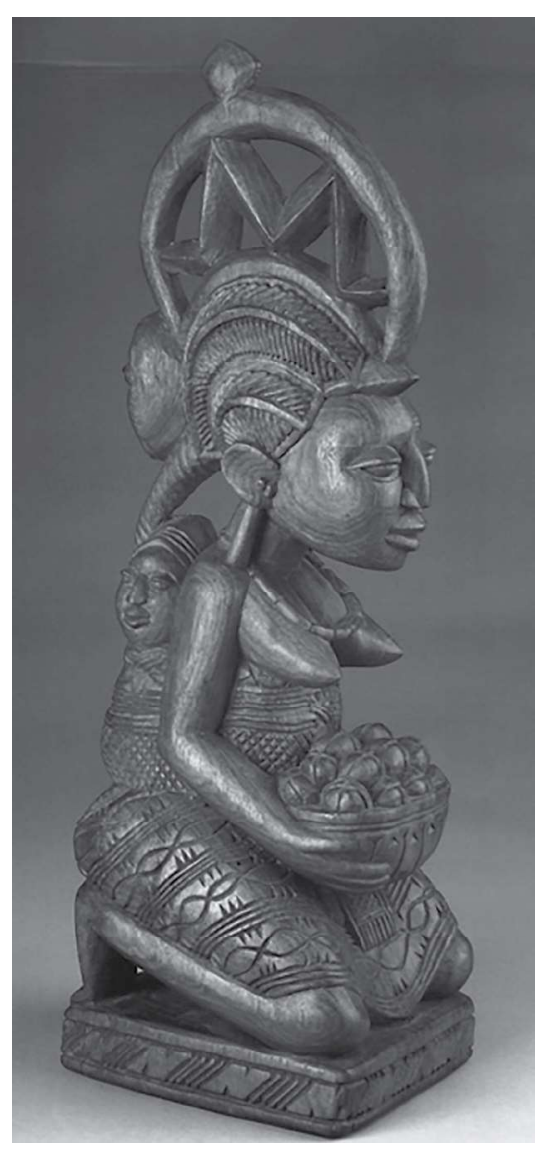

Plate 2: Kneeling figure, Arugbá Òș̣n by Lawrence Ayodele. Wood.

Ile-Ife. 1998 Photograph by Randal Stegmeyer. This artwork is reproduced with the permission of David T. Doris

1 Common elements of Yorùbá wood carvings across regions include 1:4; head:body proportion, use of patterned motifs, angularity of forms and frontality. 
The facial expression, hairdo and erect breasts of the figure are elements of beauty and sexuality with which women compulsively control control the opposite sex. Portrayal of beaded necklace and beautiful dress also reveal the figure as a representation of the goddess herself, the power to control not only the wealth of Ọșun but also to give life and bless her worshippers. The bowl of offering is a component of thanksgiving to Òșun as regards the gift of the baby fastened to her back with an òjá (sash). The òjá unites the baby to the mother the way the umbilical cord connects the baby to the mother when in the womb. The kolanut is a symbolism of the essence and sustenance of life, and also a metaphor of the continued presence of the Ọșun goddess in the yearly celebration:

Odọdún là ń rórógbó

Odoọún là ñ ráwùsá

Odún kò lè yo

Kọmo obì má gorí igbá.

(The bitter kola is seen yearly

The walnut is seen yearly

The year cannot break)

Without the appearance of kolanut on the stall).

\section{Edan Ògbóni}

The twin metal staff called Edan Ògbóni (see Plate 3) joined together by a chain is one of the symbols of the authority of the Ògbóni/Òsùgbó members. The Society comprises mainly of elders and eminent citizens of the community (Falola \& Adejumobi 2004, 366). The Ògbóni cult possesses the power with which they check the excesses of an $O b a$ (king), settle and control crises in the society. The artwork expresses the power in the unity of male and female who are members of the society towards bringing about fairness and peace among persons in their communities through their true adjudication to all.

The clenched first of the male counterpart of the pair is symbolic form of greeting in obeisance to the god of the earth who possess power to witness man's activities in the mundane world. According to Fagg and Pemberton III $(1982,186)$, the heads of the paired figures radiate the power of their ogbón (wisdom) and àșe (authority). The figures are joined together to symbolize coital union that leads to procreation and multiplication on the surface of the earth. The use of metal for the work also explains the immortality associated with ile (mother earth), as worshipped by the Ogboni. This truth is explained by this aphorism: 


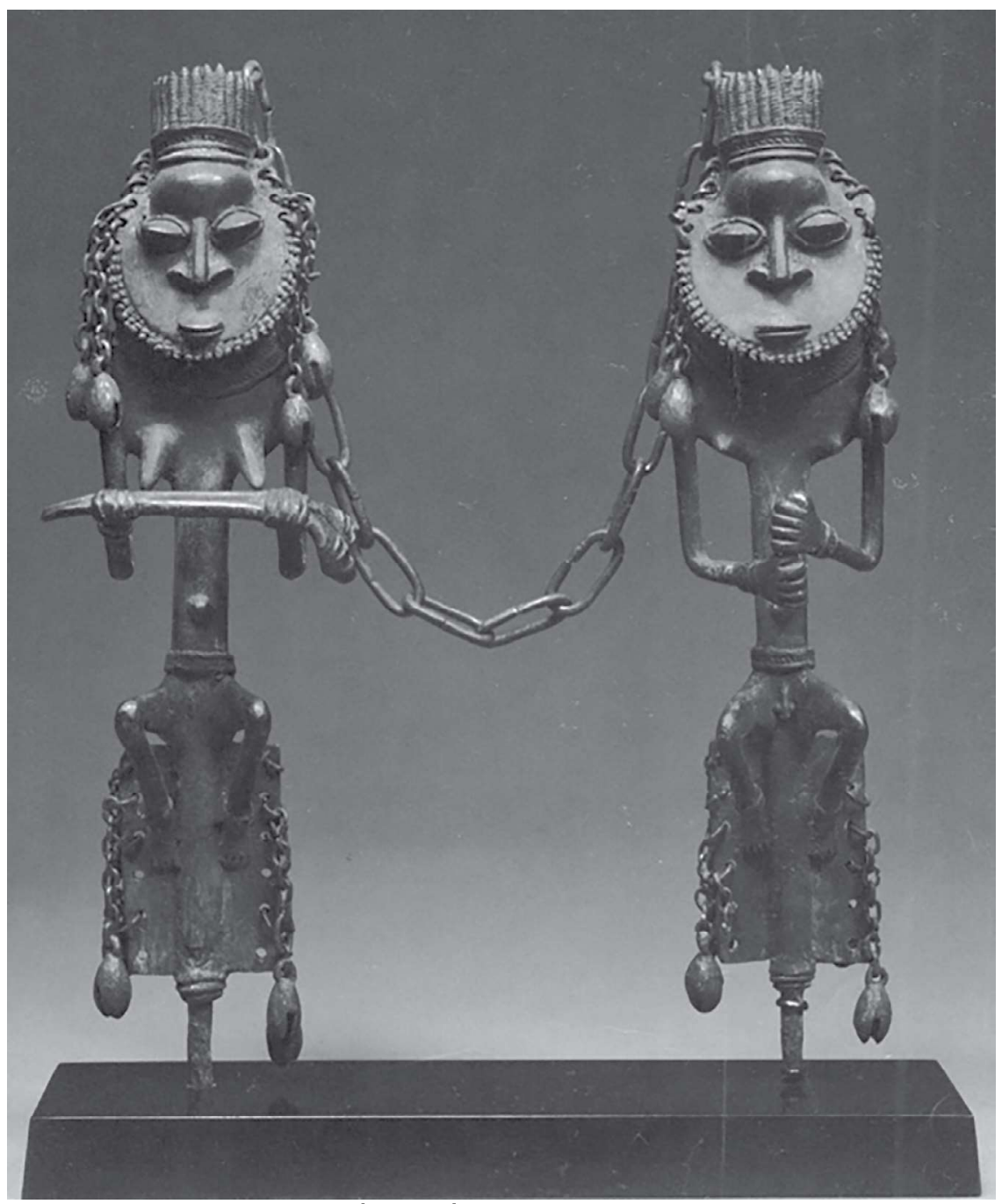

Plate 3: EdanÒgbóni/Òșùgbó. Bronze. Ijebu.Undated.

Source: Fagg W. \& Pemberton III (1982) Yorùbá Sculpture of West Africa. (Ed. Holcombe, B.) New York: Alfred A. Knopf. 
Edan kiì kú, kiì rùn

Ojú ẹdan kii fọ ní ilédì.

(Edan does not die, it does not rot

The edan do not go blind in the secret shrine-ilédi).

\section{Resist textile (Àdìre elékọ)}

Àdìre eléko is one of the finest fabric designs of the Yorùbá. Bascom (1969, 101)identifies that women do resist dying using indigo dye and imported cotton sheeting and producing pattern of quite different types from those woven in the loom. They are cheaper, accessible and good for all occasions. Other types of àdìrẹ (tie and dye) textiles are àdìre òníko, àdìre eléso and àdìre alábẹrrẹ. The work in Plate 4, titled sún-bèbè (Rock the waist-beads) portrays assorted design elements and patterns peculiar to the Yorùbá.

The use of assorted geometrical shapes for design does represent a number of esoteric symbols that cannot be understood on their face value except they are explained. Repetition of elements to reveal creative balance and visual unity is one of the strength of the artwork. Going by its title, the design reflects a harmony of color and design on the wearer and the power of attraction

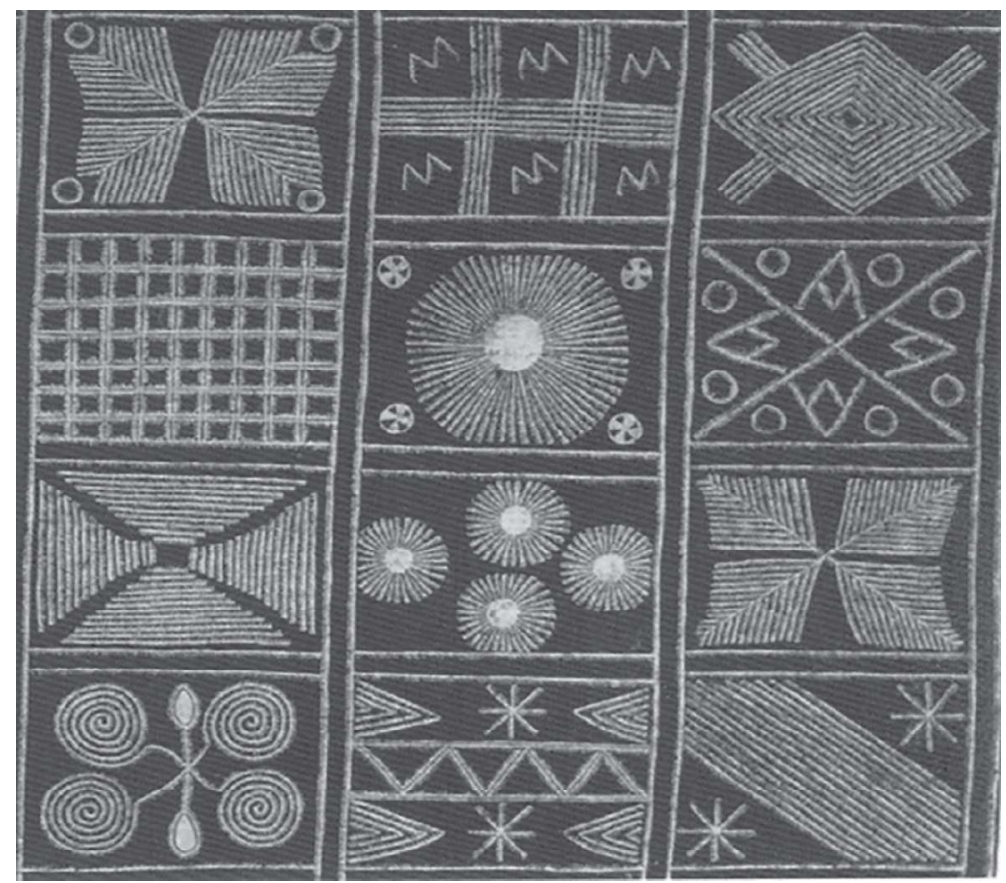

Plate 4: Àdìre ẹlẹkọ called sún-bèbè. Tie \& dye, Abeokuta or Osogbo. Undated. This artwork is reproduced from Pat Oyelola (2010). Nigerian Artisry. Ibadan: Monsuro, with the permission of Pat Oyelola, February, 2021. 
it engenders by the wearer's rocking bèbè (waist-beads). It is believed that the movement of the waste-beads underneath the cloth covering the buttocks and the attraction of the design come together to initiate an irresistible enchantment that can lead to a woman having a grip of control over the male counterparts. This must have happened when a man sings songs like this:

İsé owoó mi ni mòn șe

Má fi bèbè pa mì

(I am paying attention to my work

Don't distract me with your waist-beads).

\section{Adé ńlá (beaded crown)}

Adé ńlá (beaded crown) in Plate 5 is a mixed media work that reflects royalty. The beaded crown with its ibòjú (fringes) possesses some power on its own as an object of power. The fringes are used when the $O b a$ radiates divine power and dangerous to stare at in the face. This type of crown is a mark of olá (honor) for the $O b a$ and a symbol of his influence. The $o b a$ among the people is referred to as: aláșe ikejì òrișà (the one who wields authority, the next to the gods). He is a revered as such they pray for anyone in that position thus: kádé pé lórí kí bàtà pẹ lẹsẹ (May his crown endure, May his shoes never cease to fit).

Adé ńlá here is painstakingly crafted with beads and other materials. It is towered at the summit by the image of a eye (bird). The perching bird ${ }^{2}$, which signifies spiritual power of the 'mothers', suggest that there is a higher power capable of controlling the power of the $O b a$. The other inward-facing birds perching around the conical crown appear with a concerted unity that can be referred to as àpapò eleye (gathering of the mothers) giving support to the crown and his wearer. The crown, like a house of power is propped by the power of the birds culminating in what they referred to as: igba eké ló $n$ dá owo tí ilé (multiple posts give support to the house). The image of a face on the crown, represents the presence of the Obàtálála the god whose power oversees the actions of the wearer. There is an obvious face marks that point to the line of descent of its owner. Face marks among the Yoruba varies from place to place, and one can easily identify the lineage of the wearer by it. The decorative shapes and symbol on the crown signifies continuity as they are linked together, while also enhancing the aesthetic value of the crown. The enormous while the enormous use of beads for all its parts, which is the most precious of all materials used for making the crown, underscores the premium

2 The topmost bird from its size, prominence and position is the leader of the other birds.

3 Obàtálá, otherwise referred to as Òrìsà-ńlá is the arch-divinity. He is connected to the creation story and the moulding of human forms. 


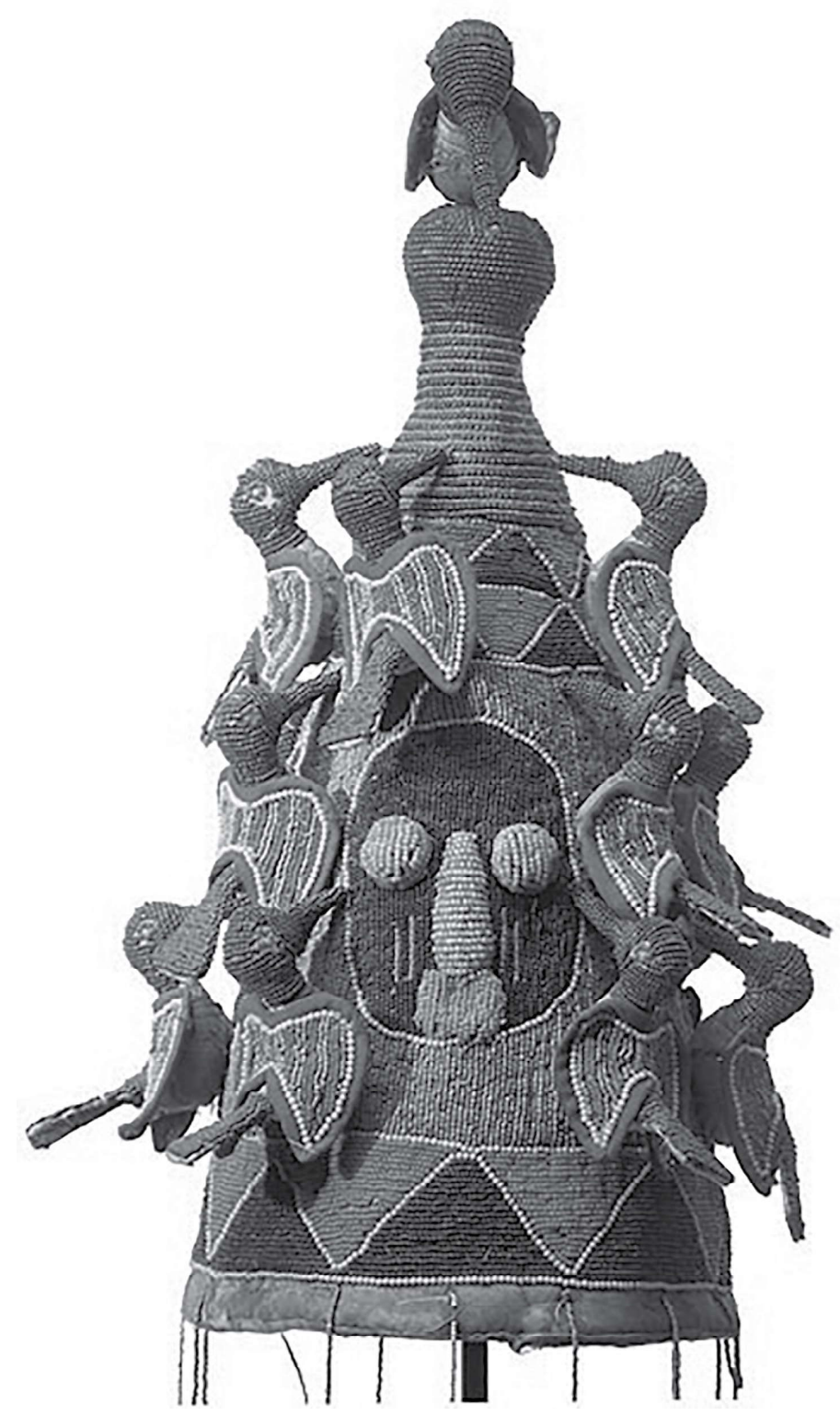

Plate 5: Adé ńlá. Beads and thread. Undated. This artwork is reproduced from www.hamillgallery.com with the permission of Timothy Hamill February, 2021. 
placed on the crown as symbol of wealth and honor. The use of beads also ensures durability, which enables the crown to survive time and seasons.

\section{Decorative Pot}

The pottery work in Plate 6 is primarily a container with the formal attributes of a woman visually represented on it: neck-beads, body adornment, headgear serving as the pot's lid, erect breasts, waist beads and other feminine features.

The pot is an image of a pregnant woman caressing her pregnancy with her two hands rendered in relief form. All women who pass through the stage of conception and also procreation will be proud to flaunt it as an evidence of her relevance in her husband's home and family as a fruitful woman and caregiver in the home. Women possess the power to rule the world from her vantage position as wife and mother. A mother is considered to be possessing power that equals that of a god: òrisà bí iyá kò sí (there is no god like a mother). The headgear stylishly rendered in the work is a reminder of the nickname: òge gèlè (the one who proudly displays her headgear with pride), which such accomplished women are fondly called because of their relevance in their husbands' homes as mothers and wives.

\section{Udamalore (Ceremonial Sword)}

The ceremonial sword made of ivory is a mark of power and status of its bearer (see Plate 7). It is used for ritual and ceremony. The holder of sword is usually from respectable family in the society. According to Visona, et al. $(2001,238)$ the holder is a man of maturity and influence whose power is felt through the land. It is about how a man's ori (inner-head), depicted at the handle end of the sword, is responsible for taking a man to a place of such honororí ló $n$ gbéni dé ipò olá.

The work reveals that the 'mother', represented by the bird, is also watching the bearer as a form of control of his excessive power. The sword serves as well as an insignia of socio-political power. The mini figure at the other end reveals the position of the sword in the right hand of the bearer. This shows how the sword is always held by the right person to perform the right ceremonies. The fact that it was made of ivory is a pointer to the title-holder's might. The linear motifs are aesthetic embellishment and symbol of continuity. 


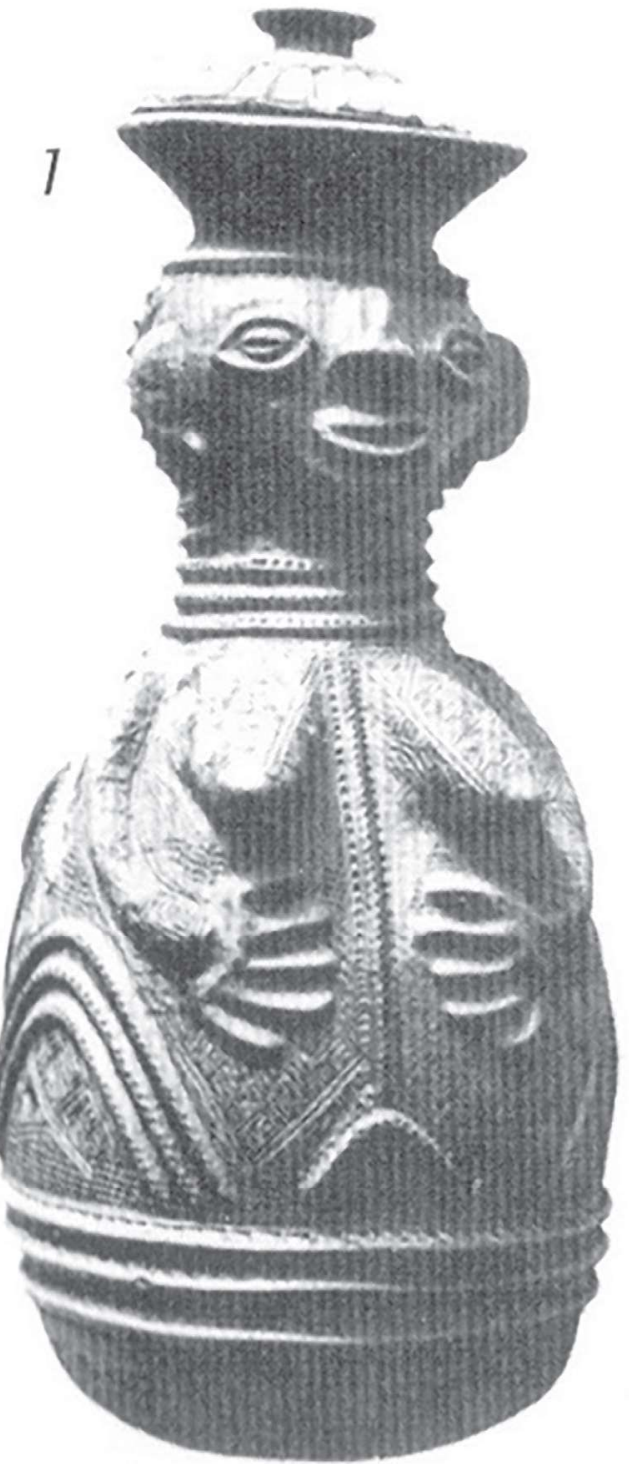

Plate 6: Decorative pot by Felicia Adepeju. Clay. Area: Igbara-Odo. 1973. This artwork is reproduced from Pat Oyelola (2010). Nigerian Artisry. Ibadan: Monsuro, with the permission of Pat Oyelola, February, 2021. 


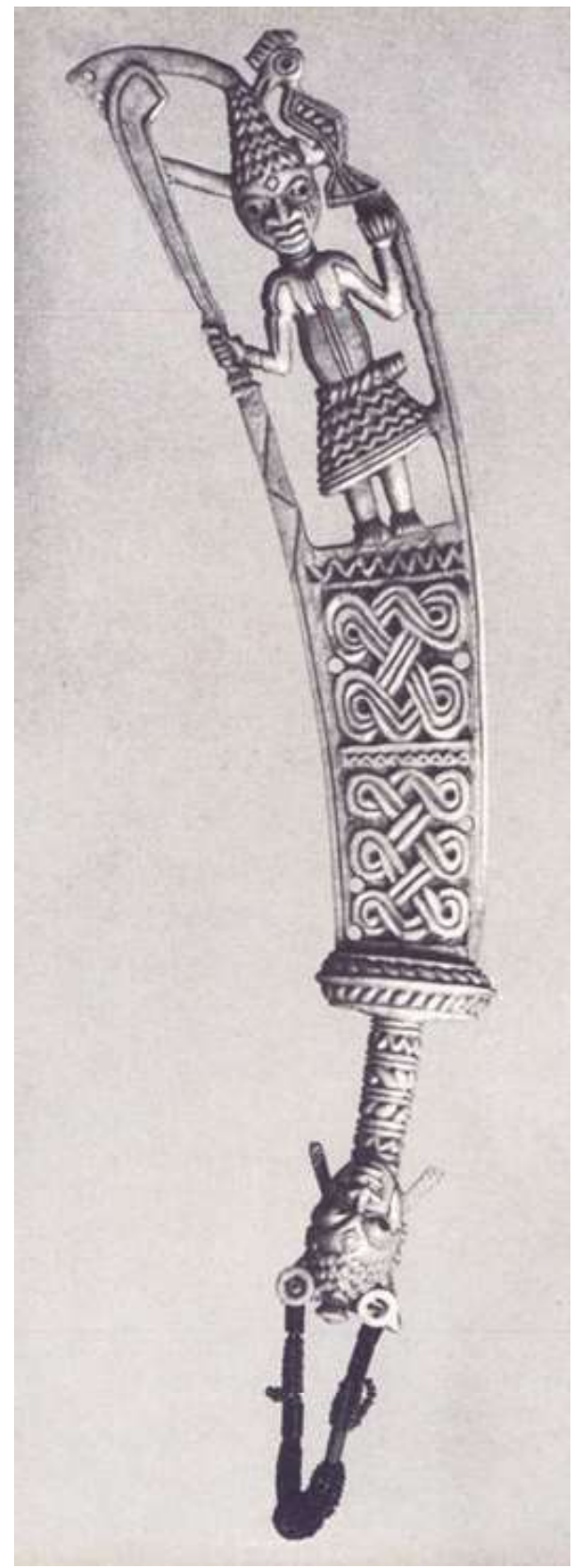

Plate 7: Udamalore (Ceremonial Sword) . Ivory. Owo. Late 19th Century.

Source: William Fagg/Herbert List (1963)

Nigerian Images. London: Lund Humphries. Pub. Ltd. 


\section{VIII. Ògún Shrine Mural Painting}

The mural in Plate 8 is populated by images of multiple faces representing the presence of the spirits/gods. The images in the mural vary in shapes, sizes and shades symbolizing the unity of numerous sprits that are represented by the shrine. Campbell $(2008,151)$ describes the faces as ancestors and the enthusiastic worshipers of Ògún. The painting also includes the images of ajá (dog), which is referred to as Ògún's delicacy. The snake image in the painting symbolizes the power of Ògún to whom the shrine is designated. Ògún possesses power to punish evildoers towards controlling the excesses of man like betrayal and deceits, but also protecting his worshipers. An Ògún praise chant reveals thus:

\section{Bí omodé bá dalè}

Kí ó ma șe da Ògún

E má ba Ògún fi ìjò șeré

Ara Ògún kan gógó.

(If a child betrays

He should not attempt to betray Ògún

Do not provoke Ògún to a fight

Ògún is highly temperamental).

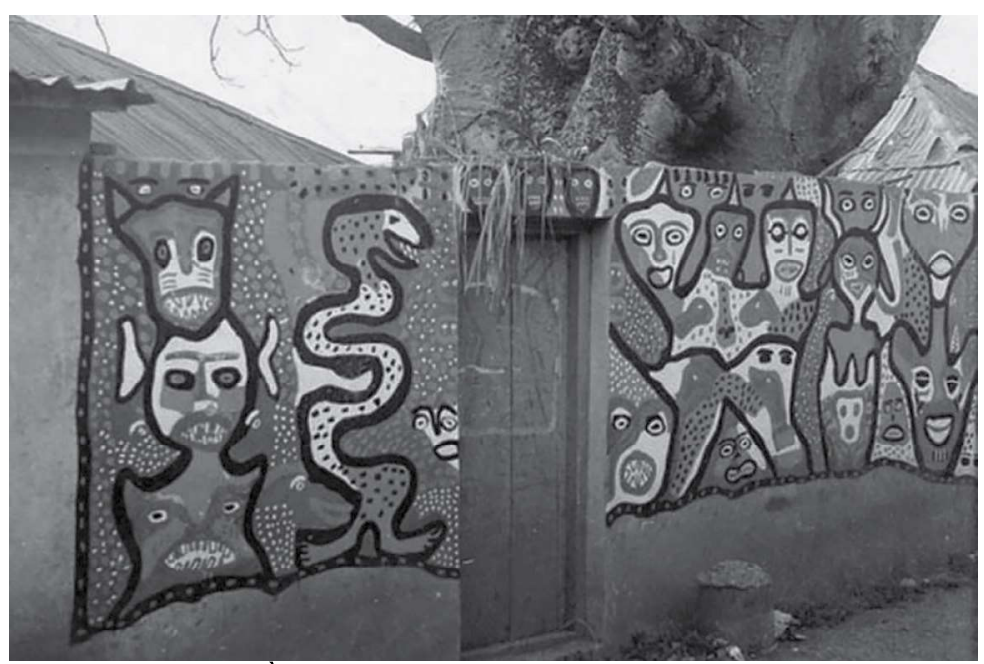

Plate 8: Òún Shrine mural. Gloss paints. Ilesa. 1987.

This artwork is reproduced with the permission Bolaji Campbell, February 2021. 
The painting shows the power of Ògún who is reputable as patron of forgers of metal objects for functional use and punishing of offenders. It calls the attention of the passers-bye to the Ògún to whom the shrine is dedicated.

\section{IX: Building Ornamentation}

Yorùbá people has been in the act of building permanent structure using mud before the abolition of slave trade which led to Africans from South America to returns home. The returnees slave brought back to Africa some professional skills, which reflected greatly in the development of Yorùbá architecture. The building in Plate 9 is Afro-Brazilian styled, which was adopted and spread all over most Yorùbá cities. The symbolic communicative embellishment known with the Yorùbá people was not left behind, rather upgraded with the use of stucco and cement that make it to be more durable on the building. The Afro-Brazilian house with the inscription "Olọrun ò șebi" on its balcony concrete rail is located at Ikorodu. At the upper part is a stylish wall attached to the roof having a low relief of palm tree motif painted in light green. Palm tree is an economic tree for the production of palm oil and plank for building purposes. Adepegba $(2014,82)$ notes that apart from the owner of the house saying that he is taller than his contemporaries; he is indicating how agriculture serves as a means of socio-economic power among the people. The image is on the pediment of the house in a vantage position to communicate the essence of this form of power to the people. Farming as a focus has the potential of breaking the power of and controlling hunger: $t$ ébi bá kúrò nínú isé, isé bùse (If hunger is taken care of, poverty is half-solved).

\section{Conclusion}

The analysis offered in this paper has enable us to understand the symbol of some images found on art forms and how they have helped to project the belief about and philosophy of power and control among the Yorùbá. The works showcased reflect the artistry of the people and show the interrelatedness of types of power among the people and how they culminate in cultural power as exemplified by the artistic creations of the people. It has also showed how various visual art forms serve as symbolism of power and control among the people.

Essentially, the art forms examined have revealed the visual symbolism in the forms of humans, animals, plants/crops, non-living objects and geometric elements, which communicate the characteristic nature of power and his symbolism among the people in the course of the age-long development of the Yorùbá nation. 


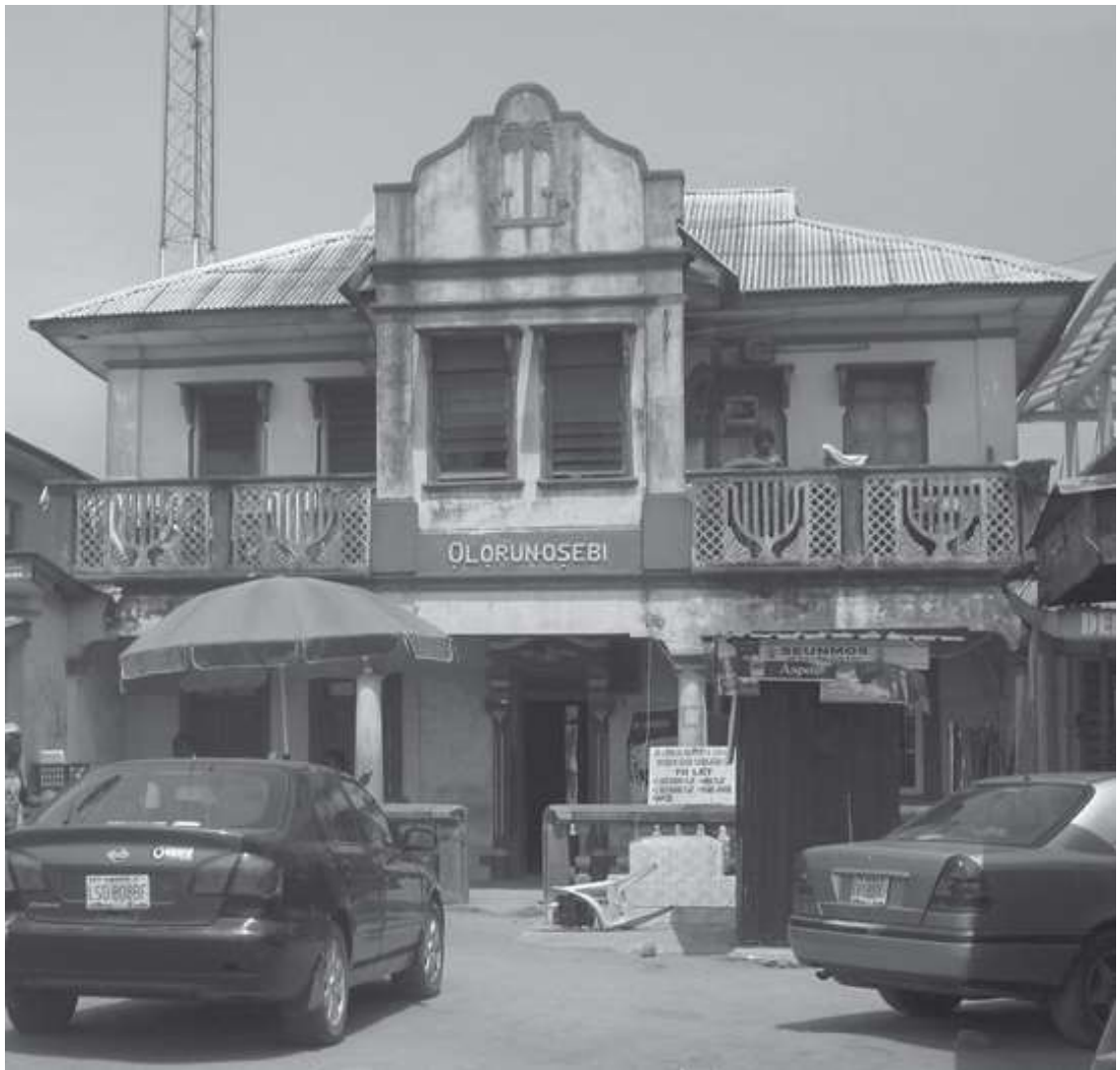

Plate 9: Building ornamentation. Cement Relief. Ikorodu. Mid. 20th Century.

Photograph: Kehinde Adepegba, 2014.

\section{Bibliography}

Adeoye, C. L. Àsààti İseYorùbá. Ibadan: University Press, 1979.

Adepegba, K. "A Study of the Artistic Tradition of Àgbó Rémirékè Masquerade in Agbowaİkosì," Lagos State. Unpublished MA thesis, Obafemi Awolowo University, Ile-Ife(Nigeria), 2016.

Adepegba, K. Contemporary Yorùbá Woodcarving. Lagos: Aramanda Creations, 2007.

Adepegba, K. "A Study of Ikorodu Vernacular Architecture and its Decorative Motifs." Journal

of Environmental Design and Management 6.1\& 2. (2014): 75-85

Bascom, W. The Yorùbá of South-Western Nigeria. New York: Holt, Rinehart and Winston 1969.

Campbell, B. Painting for the Gods: Art and Aesthetics of Yorùbá Religious Murals. Eritrea: Africa World Press. 2008. 
Carroll, K.Yorùbá Religious Carving: Pagan \& Christian Sculpture in Nigeria \& Dahomey.

London: Geoffrey Chapman, 1966.

Fagg, W., and J. Pemberton III. Yorùbá Sculpture of West Africa. New York: Alfred A. Knopf,

1982.

Falola,T., and S. A. Adejumobi.“Iron Smiting and Jewelry Making." In Understanding YorùbáLife \& Culture, eds.Lawal, Sadiku \& Dopamu), 361-76. Asmara (Eritrea): Africa WorldPress, 2004.

Folarin, A. “Sculpture.” In Understanding Yorùbá Life \& Culture, eds. Lawal, Sadiku \&

Dopamu, 35-60.Asmara (Eritrea): Africa World Press, 2004.

Frazer, D., and H. M. Cole. "Art \& Leadership: An Overview." In African Art \& Leadership,eds. Fraser \& Cole, 295-328. Madison, Wisconsin (USA): University of WisconsinPress, 1972.

Hackett, R. I. J.Art and Religion in Africa. London: Cassell, 1996.

Jefferson, L. E.The Decorative Arts of Africa. London: St. James's Place, 1974.

Kalilu, R., and M. Areo. "Cross-currents and Transmigration of Motifs of Yoruba."

AFRREVIJAH, 2.6. (2013): 108--129.

Kissick, J. Art Context and Criticism. Iowa: WCB Brown \& Benchmark, 1993.

Lawal, B. "Embodying the Sacred in Yorùbá Art." Embodying the Sacred in Yorùbá Art:Selections from the Newark Museum Collections. (2012): $11-23$

Pemberton III, J. "Introduction: In Praise of Artistry." In The Yorùbá Artist. Eds. Abiodun,Drewal, Pemberton III, 119-136.Washington (USA): Smithsonian Institution Press, 1994.

Visoná, Monica Blackmun, et al. History of Art in Africa. New York: Harry N. Abrams, 2001.Oral Literature: Òwe (Proverbs), Orin (Songs) and Oríkì (Praise chants) 